\title{
A RAPD-PCR-based genetic diversity analysis of Helicoverpa armigera and $H$. zea populations in Brazil
}

\author{
H.M. Lopes ${ }^{1}$, C.S. Bastos ${ }^{1}$, L.S. Boiteux ${ }^{2}$, J. Foresti ${ }^{3}$ and F.A. Suinaga ${ }^{2}$ \\ ${ }^{1}$ Faculdade de Agronomia e Veterinária, \\ Universidade de Brasília, Brasília, DF, Brasil \\ ${ }^{2}$ Embrapa Hortaliças, Brasília, DF, Brasil \\ ${ }^{3}$ Pioneer Seeds, Brasília, DF, Brasil \\ Corresponding author: F.A. Suinaga \\ E-mail: fabio.suinaga@embrapa.br
}

Genet. Mol. Res. 16 (3): gmr16038757

Received May 3, 2016

Accepted August 16, 2017

Published September 21, 2017

DOI http://dx.doi.org/10.4238/gmr16038757

Copyright $(92017$ The Authors. This is an open-access article distributed under the terms of the Creative Commons Attribution ShareAlike (CC BY-SA) 4.0 License.

\begin{abstract}
Helicoverpa armigera is the most significant pest of agriculture in Asia, Europe, Africa, and Australasia, causing damage to crops greater than US\$2 billion annually and until 2013 it was not detected in Brazil. Helicoverpa zea is restricted to the American continent and is important to corn and a secondary pest of cotton and tomatoes. The wide range of crops exploited by $H$. armigera (mainly cotton, soybeans, chickpea, and corn), the possible mating between these species can promote population shifts, that could be assessed by RAPDPCR technique. Therefore, the aim of this study was to determine the genetic diversity of $H$. armigera and $H$. zea populations by RAPD-PCR analysis. The most important result was the clustering of one $H$. armigera population in a group predominantly formed by $H$. zea. It could indicate a possible occurrence of an interspecific cross between these species. This is a concern to Brazilian agriculture due to the possibility of selection of hybrids well adapted to the American environment, which would be
\end{abstract}


inherited from $H$. zea. The other noxious fact is the possible development of new biotypes resistant to insectides or Bt toxins expressed in transgenic crops, came from $H$. armigera gene pool.

Key words: Old World bollworm; Corn earworm; Molecular markers; Population genetics; Genetic diversity

\section{INTRODUCTION}

The Helicoverpa and Heliothis are the two most important genera of agricultural pests within the Heliothinae subfamily (Lepidoptera: Noctuidae) (Pogue, 2013). According to Tay et al. (2013), Helicoverpa armigera is the most significant and impactful pest of agriculture in Asia, Europe, Africa, and Australasia, causing damage to crops estimated at greater than US\$2 billion annually, excluding socio-economic and environmental costs associated with its control. In Brazil, regarding the agricultural years of 2012/2013, Spadotto et al. (2014) pointed out that decreasing yields and rise in phytosanitary costs in cotton, corn, beans, sorghum, and millet resulted in US\$ 2 billion of loss. On the other hand, Helicoverpa zea is an important pest of corn and a secondary one for cotton and tomatoes and is restricted to American continent (King and Coleman, 1989). According to Bird and Downes (2014), chemical control and transgenic crops expressing Bt toxins are the main strategies to control $H$. armigera and $H$. zea.

In Brazil, $H$. armigera was considered as an A1 quarantine pest (not present, but of potential economic importance). However, the recent invasion of $H$. armigera populations into Brazilian crops has been independently confirmed by Czepack et al. (2013), Specht et al. (2013) and Tay et al. (2013). The introduction of H. armigera in the country is a major threat to Brazilian agriculture due to the following characteristics of this pest: a) long-distance dispersion (Farrow, 1984; Pedgley, 1985); b) wide range of host plants (Behere et al., 2013); c) high fecundity (Subramanian and Mohankumar, 2006); d) resistance to several insecticides (Bird and Downes, 2014); e) potential risk of resistance to Bacillus thuringiensis (Bt) proteins expressed in transgenic crops (Nair et al., 2013); f) possibility of interspecific crosses with $H$. $z e a$ populations and generation of fertile hybrid offspring (Laster and Sheng, 1995).

According to Behere et al. (2013), these characteristics alone or combined can alter the structure and population dynamics of this insect. Furthermore, evolutionary factors can imply in ecological specialization and adaptation to a particular host and these could shift the genetic flow between populations of this insect (Zalucki et al., 2012). In the specific case of $H$. armigera, Zhou et al. (2000) remarked that a high level of gene flow could allow spread of insecticide resistance genes in susceptible populations when this selective pressure is present, which is the case of several Brazilian agricultural systems. Regarding the interspecific cross between $H$. armigera and $H$. zea, the concern is the selection of hybrids well adapted to the new environment (American continent) and/or development of new biotypes resistant to insecticides or Bt toxins expressed in transgenic crops (cotton, maize, and soybeans) (Leite et al., 2014).

In this context, several molecular strategies have been used for genetic and evolutionary studies at population level (Guerra et al., 2010). One of these strategies is the PCR-based randomly amplified polymorphic DNA (RAPD), which is a type of polymerase chain reaction where the fragments of DNA are randomly amplified, using short synthetic oligonucleotides of random sequence (Williams et al., 1990). The RAPD marker system has many advantages, including the low cost, little technical demands, and no prior knowledge about DNA sequence

Genetics and Molecular Research 16 (3): gmr16038757 
(Bhau et al., 2014). Besides, according to Anbalagan et al. (2012), RAPD marker system is suitable for studies of population structure because it allows for the detection of polymorphisms in coding and non-coding regions of both nuclear and mitochondrial genomes.

In this context, the objective of this study was to assess the genetic divergence among $H$. armigera and H. zea populations using information generated by the RAPD marker system.

\section{MATERIAL AND METHODS}

\section{Specimens}

H. armigera and H. zea laboratory-reared caterpillars collected in Midwest, South and Southeast regions from Brazil were used in the present study. The identification of the Helicoverpa populations at species level was done via sequencing of a taxonomically informative segment of the mitochondrial DNA (mtDNA) cytochrome oxidase I (COI) gene and comparing the obtained sequences with the available $H$. armigera and $H$. zea barcode (Behere et al., 2008; Tay et al., 2013) sequences using the BLASTn tool. In total, five H. armigera and eight $H$. zea populations were included in the present study. All samples were preserved in $75 \%$ ethanol and stored at $-20^{\circ} \mathrm{C}$ prior to DNA extraction. The population codes, sampling dates, plant hosts, geographic coordinates and sampling sites are described in Table 1.

Table 1. Abbreviation, number of individuals/sample, sampling date, host plant, geographic coordinates, and sampling sites of 12 Helicoverpa armigera (HA) and Helicoverpa zea (HZ) populations collected in Brazil.

\begin{tabular}{|c|c|c|c|c|c|c|}
\hline Abbreviation* & $\mathrm{N}$ & Sampling date & Host plant & Geographic coordinates & Sites $^{1}$ (Cities-States) & Climate \\
\hline HA-BA & 8 & $10 / 24 / 2014$ & Cotton & $\begin{array}{l}11^{\circ} 19^{\prime} 40,1^{\prime \prime S} \\
46^{\circ} 11^{\prime} 16,8^{\prime \prime} \mathrm{W}\end{array}$ & Formosa do Rio Preto-BA & Tropical (Aw) \\
\hline HA-DF1 & 15 & $01 / 22 / 2014$ & Soybean & $\begin{array}{l}15^{\circ} 43^{\prime} 30,0^{\prime \prime} \mathrm{S} \\
47^{\circ} 36^{\prime} 39,0^{\prime \prime} \mathrm{W}\end{array}$ & Brasília-DF & Tropical (Aw) \\
\hline HA-DF2 & 10 & $12 / 17 / 2013$ & Soybean & $\begin{array}{l}15^{\circ} 43^{\prime} 11,9^{\prime \prime} \mathrm{S} \\
47^{\circ} 35^{\prime} 51,8^{\prime \prime} \mathrm{W}\end{array}$ & Brasília-DF & Tropical (Aw) \\
\hline HA-SP & 20 & $11 / 04 / 2014$ & Soybean & $\begin{array}{l}22^{\circ} 45^{\prime} 40,0^{\prime \prime} \mathrm{S} \\
47^{\circ} 09^{\prime} 15,0^{\prime \prime} \mathrm{W}\end{array}$ & Paulínea-SP & Subtropical (Cfa) \\
\hline HZ-DF1 & 20 & $11 / 11 / 2014$ & Soybean & $\begin{array}{l}15^{\circ} 52^{\prime} 07,0^{\prime \prime} \mathrm{S} \\
47^{\circ} 24^{\prime} 3,50^{\prime \prime} \mathrm{W}\end{array}$ & Brasília-DF & Tropical (Aw) \\
\hline HZ-DF2 & 20 & $11 / 13 / 2014$ & Sweetcorn & $\begin{array}{l}15^{\circ} 57^{\prime} 2,0^{\prime \prime} \mathrm{S} \\
47^{\circ} 56^{\prime} 2,0^{\prime \prime} \mathrm{W}\end{array}$ & Brasília-DF & Tropical (Aw) \\
\hline HZ-DF3 & 20 & $01 / 09 / 2014$ & Corn & $\begin{array}{l}15^{\circ} 43^{\prime} 30,0^{\prime \prime} \mathrm{S} \\
47^{\circ} 36^{\prime} 39,0^{\prime \prime} \mathrm{W}\end{array}$ & Brasília-DF & Tropical (Aw) \\
\hline HZ-GO1 & 10 & $07 / 25 / 2014$ & Corn & $\begin{array}{l}18^{\circ} 20^{\prime} 25,9^{\prime \prime} \mathrm{S} \\
49^{\circ} 11^{\prime} 11,03^{\prime \prime} \mathrm{W}\end{array}$ & Itumbiara-GO & Tropical (Aw) \\
\hline HZ-GO2 & 10 & $10 / 01 / 2014$ & Corn & $\begin{array}{l}18^{\circ} 20^{\prime} 27,9^{\prime \prime} \mathrm{S} \\
49^{\circ} 11^{\prime} 11,0^{\prime \prime} \mathrm{W}\end{array}$ & Itumbiara-GO & Tropical (Aw) \\
\hline HZ-GO3 & 12 & $10 / 15 / 2014$ & Corn & $\begin{array}{l}17^{\circ} 43^{\prime} 52,0^{\prime \prime} \mathrm{S} \\
49^{\circ} 05^{\prime} 58,0^{\prime \prime} \mathrm{W}\end{array}$ & Morrinhos-GO & Tropical (Aw) \\
\hline HZ-PR & 10 & $01 / 06 / 2015$ & Corn & $\begin{array}{l}24^{\circ} 42^{\prime} 45,0^{\prime \prime} \mathrm{S} \\
53^{\circ} 44^{\prime} 35,0^{\prime \prime} \mathrm{W}\end{array}$ & Toledo-PR & Subtropical (Cfa) \\
\hline HZ-SC & 10 & $01 / 19 / 2015$ & Corn & $\begin{array}{l}26^{\circ} 45^{\prime} 39,5^{\prime \prime} \mathrm{S} \\
53^{\circ} 10^{\prime} 21,0^{\prime \prime} \mathrm{W}\end{array}$ & Maravilha-SC & Subtropical (Cfa) \\
\hline
\end{tabular}

${ }^{1}$ Abbreviations of the collection sites: $\mathrm{BA}=$ Bahia State; $\mathrm{DF}=$ The Federal District; $\mathrm{GO}=$ Goiás State; $\mathrm{SP}=\mathrm{São}$ Paulo State; $\mathrm{PR}=$ Paraná State, and $\mathrm{SC}=$ Santa Catarina State.

\section{DNA extraction}

Genomic DNA was extracted from the last three abdominal segments of the larvae (Behere et al., 2013) from eight individual caterpillars in each population, following a 
modified cetylmethylammonium bromide (CTAB) protocol (Subramanian and Mohankumar, 2006). Larvae were ground with $1.0 \mathrm{~mL} 2 \%$ cetyl trimethyl ammonium bromide buffer (CTAB), $100 \mathrm{mM}$ Tris-HCI (pH 8.0), $1.4 \mathrm{M}$ sodium chloride, $20 \mathrm{mM}$ EDTA, and $0.1 \%$ 2-mercaptoethanol. This mixture was incubated at $65^{\circ} \mathrm{C}$ for $2 \mathrm{~h}$ and then equal volume of chloroform: isoamylalcohol (24:1) was added. The suspension was centrifuged at $800 \mathrm{~g}$ for 15 $\min$ at $4{ }^{\circ} \mathrm{C}$. Then, the DNA was precipitated by adding equal volume of ice-cold isopropanol, centrifuged at $8000 \mathrm{~g}$ and the pellet was washed with $70 \%$ ethanol and dissolved in $100 \mu \mathrm{L}$ of TE + RNase (10 mM Tris-HCl, 1 mM EDTA, $8 \mu \mathrm{L}$ RNase, $\mathrm{pH}$ 8.0) and short term stored at $4^{\circ} \mathrm{C}$. The DNA from each sample was quantified by spectrophotometry (NanoDrop 2000 spectrophotometer, Thermo Fischer Scientific, USA) and the concentrations were adjusted with TE + RNase to get a working solution of $20 \mathrm{ng} / \mu \mathrm{L}$.

\section{RAPD-PCR}

The initial screening for molecular polymorphisms among the pest total DNA samples was performed with 120 oligonucleotide primers (Operon Technologies, USA). Sixteen primers were chosen based upon the production of scorable amplicons (bands) across the Helicoverpa populations (Table 2). Each RAPD-PCR was performed in a total volume of $25 \mu \mathrm{L}$ containing $40 \mathrm{ng}$ DNA template, $2.5 \mu \mathrm{L}$ 10X TaqDNA polymerase buffer, $1.5 \mathrm{mM} \mathrm{MgCl}_{2}, 0.5 \mathrm{U}$ Taq DNA polymerase (Invitrogen, Brazil), $0.2 \mathrm{mM}$ of each dNTP, 20 pmol primer and sufficient Milli Q sterile water to complete the final volume. PCR was performed in a GeneAmp ${ }^{\circledR}$ PCR System 9700 thermal cycler (Applied Biosystems, USA) programmed with one cycle of initial denaturation at $94^{\circ} \mathrm{C}$ for $1 \mathrm{~min} ; 35$ cycles each of $94^{\circ} \mathrm{C}$ for $30 \mathrm{~s}$, annealing at $36^{\circ} \mathrm{C}$ for $1 \mathrm{~min}$, extension at $72^{\circ} \mathrm{C}$ for $1 \mathrm{~min}$ and $30 \mathrm{~s}$, and final extension at $72^{\circ} \mathrm{C}$ for $7 \mathrm{~min}$. The PCR products were separated on a $1.5 \%$ agarose gel stained with ethidium bromide $(10 \mathrm{mg} / \mathrm{mL})$ in 1 X TBE buffer, using $1 \mathrm{~kb}$ plus DNA ladder (Invitrogen, USA) as a molecular weight standard. Gels were visualized and photographed under UV light using the Quantity One ${ }^{\circledR}$ (BioRad, USA) software. This procedure was repeated using the same equipment, supplies, and DNA template in order to confirm the band patterns.

Table 2. Sixteen genetically informative RAPD primers and their respective number of polymorphic amplicons observed after analyzing total genomic DNA of 12 Helicoverpa armigera and $\mathrm{H}$. zea populations collected across four geographic Brazilian regions.

\begin{tabular}{l|l}
\hline Primer code & Primer sequence $\left(5^{\prime}-3^{\prime}\right)$ \\
\hline OPA-02 & TGCCGAGCTG \\
\hline OPA-07 & GAAACGGGTG \\
\hline OPA-12 & TCGGCGATAG \\
\hline OPA-14 & TCTGTGCTGG \\
\hline OPA-16 & AGCCAGCGAA \\
\hline OPB-01 & GTTTCGCTCC \\
\hline OPC-01 & TTCGAGCCAG \\
\hline OPC-02 & GTGAGGCGTC \\
\hline OPC-04 & CCGCATCTAC \\
\hline OPC-05 & GATGACCGCC \\
\hline OPC-06 & GAACGGACTC \\
\hline OPC-11 & AAAGCTGCGG \\
\hline OPC-13 & AAGCCTCGTC \\
\hline OPC-20 & ACTTCGCCAC \\
\hline OPF-02 & GAGGATCCCT \\
\hline
\end{tabular}

Genetics and Molecular Research 16 (3): gmr16038757 


\section{Statistical analysis}

The presence ' 1 ' or absence ' 0 ' of bands in each population for each selected primer was visually scored on the gel and entered into a binary matrix. Loci were selected for which the most common allele in each population occurred at a frequency greater than or equal to $75 \%$, as suggested by McMichael and Prowell (1999). The data matrix was used to calculate the arithmetic complement of Jaccard index (Sneath and Sokal, 1973). Based on this information, a dendrogram was obtained by using the unweighted pair group method with arithmetic average (UPGMA) with bootstrapping (500 replicates). Moreover, the dissimilarity values were used in other two cluster analysis, one based on the Tocher method (Rao, 1952) and the other using a principal component analysis (PCA) bidimensional scatter plot. UPGMA and principal component analysis were performed by the NTSYS software version 2.02 (Rohlf, 2000) and Tocher's cluster analysis was done using the GENES software package (Cruz, 2013).

\section{RESULTS}

One-hundred seventeen (117) polymorphic amplicons were obtained with a set of 16 RAPD primers selected in preliminary screening assays (Figure 1). The number of informative bands for each primer in each population ranged from 4 to 12 with a mean of 7.5. The amplicon sizes ranged from 200 to $3000 \mathrm{bp}$. Based on Jaccard index the highest genetic distance was found between HA-DF2 and HA-BA (0.86). On the other hand, the lowest distances were observed between HZ-GO2 and HZ-GO3 (0.06), and HZ-PR and HZ-SC (0.06) (Table 3). Genetic relationships between Helicoverpa populations can also be observed in Table 3, where the average genetic distance was 0.68 for $H$. armigera and 0.37 for $H$. zea.

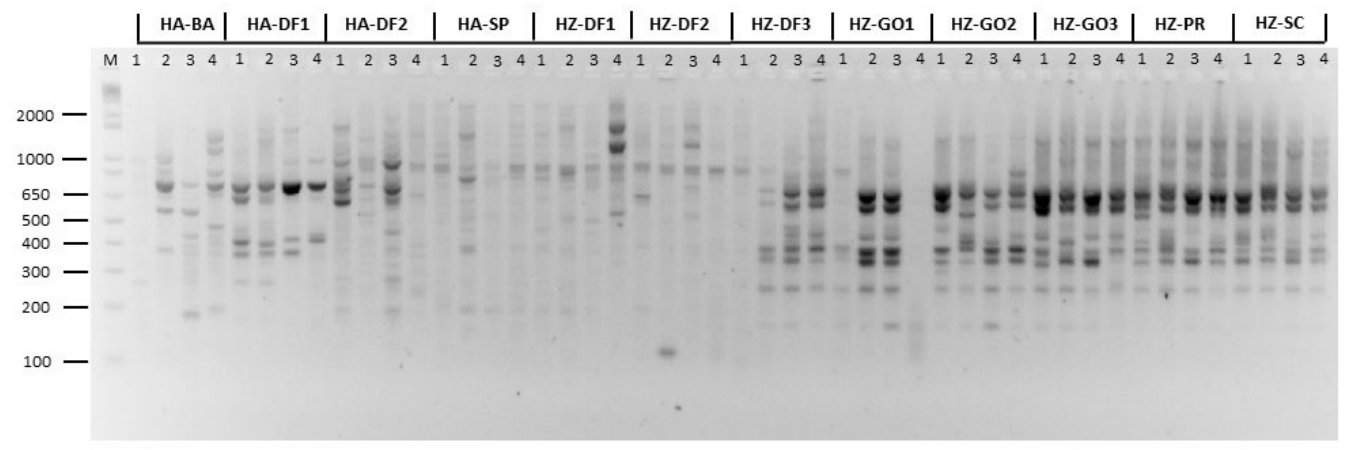

Figure 1. DNA samples from four caterpillars of twelve different populations of Helicoverpa spp amplified with RAPD primer OPC13. Population acronyms details are present in Table 1 . Lane $M=$ size markers (1 kb plus DNA ladder from Invitrogen).

The dendrogram, based on UPGMA, separated Helicoverpa populations in three distinct groups (Figure 2). The group 1 was composed by all H. zea populations, except HZGO1. The group 2 was formed by two populations of $H$. armigera (HA-BA and HA-SP) and the third cluster (group 3) was composed by two populations of $H$. armigera (HA-DF1 and HA-DF2) and one of H. zea (HZ-GO1). 
Table 3. Pairwise dissimilarity matrix of 12 populations of Helicoverpa armigera and H. zea according to Jaccard index using genetic information derived from 117 polymorphic RAPD-PCR bands obtained in the amplification profiles of 16 RAPD primers.

\begin{tabular}{l|c|c|c|c|c|c|c|c|c|c|c|c}
\hline & HA-BA & HA-DF1 & HA-DF2 & HA-SP & HZ-DF1 & HZ-DF2 & HZ-DF3 & HZ-GO1 & HZ-GO2 & HZ-GO3 & HZ-PR & HZ-SC \\
\hline HA-BA & 0.00 & & & & & & & & & & & \\
\hline HA-DF1 & 0.85 & 0.00 & & & & & & & & & & \\
\hline HA-DF2 & 0.86 & 0.33 & 0.00 & & & & & & & & \\
\hline HA-SP & 0.58 & 0.68 & 0.70 & 0.00 & & & & & & & \\
\hline HZ-DF1 & 0.61 & 0.80 & 0.81 & 0.60 & 0.00 & & & & & & & \\
\hline HZ-DF2 & 0.62 & 0.71 & 0.73 & 0.56 & 0.28 & 0.00 & & & & & & \\
\hline HZ-DF3 & 0.66 & 0.82 & 0.83 & 0.59 & 0.30 & 0.27 & 0.00 & & & & & \\
\hline HZ-GO1 & 0.83 & 0.30 & 0.35 & 0.64 & 0.79 & 0.35 & 0.79 & 0.00 & & & & \\
\hline HZ-GO2 & 0.62 & 0.80 & 0.82 & 0.59 & 0.21 & 0.21 & 0.17 & 0.80 & 0.00 & & & \\
\hline HZ-GO3 & 0.62 & 0.82 & 0.84 & 0.61 & 0.26 & 0.21 & 0.20 & 0.84 & 0.06 & 0.00 & & \\
\hline HZ-PR & 0.62 & 0.78 & 0.80 & 0.61 & 0.23 & 0.25 & 0.24 & 0.79 & 0.15 & 0.16 & 0.00 & \\
\hline HZ-SC & 0.62 & 0.79 & 0.81 & 0.59 & 0.20 & 0.20 & 0.19 & 0.78 & 0.10 & 0.10 & 0.06 & 0.00 \\
\hline
\end{tabular}

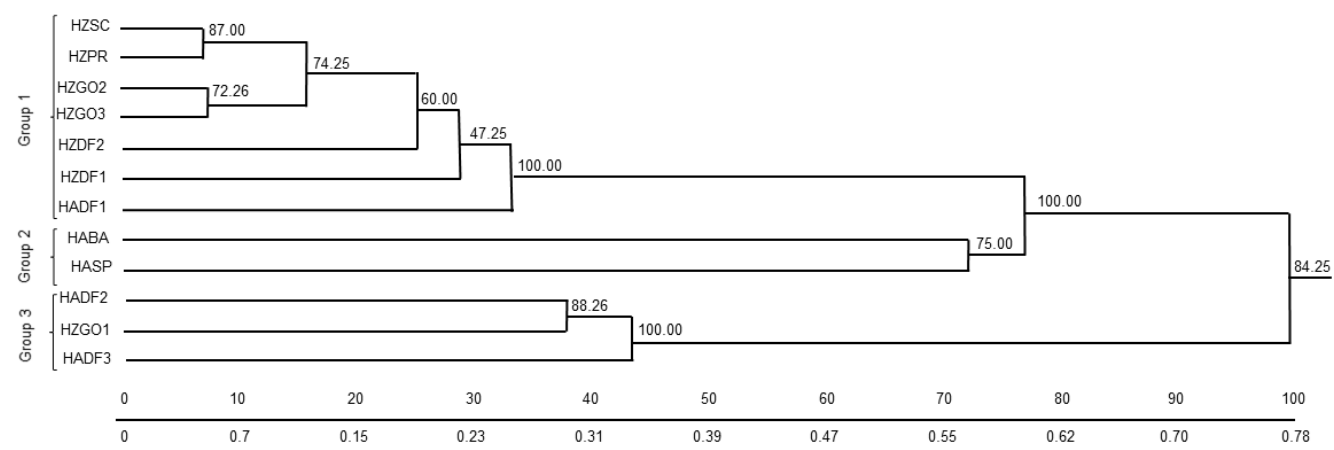

Figure 2. UPGMA dendrogram of 12 populations of Helicoverpa spp based on Jaccard index. Bootstrap support (percent of 400 replicates) is indicated for each branch.

As regarded in cluster analysis based on the Tocher method (Table 4), all Helicoverpa populations were subdivided into three groups. The group 1 was formed by all evaluated populations of $H$. zea except HZ-GO1. The group 2 involved two populations of $H$. armigera and one of $H$. zea and group 3 was composed by the remaining populations of $H$. armigera (HA-BA and HA-SP). Besides, considering the average distance within and between groups, it could be inferred that the most divergent groups were 1 and 2 (16.67) and the least variable was the group $3(0.58)$.

Table 4. Average distance within and among clusters of 12 Helicoverpa populations based on Tocher's methodology using genetic information derived from 117 polymorphic RAPD-PCR bands obtained in the amplification profiles of 16 RAPD primers.

\begin{tabular}{l|c|c|c}
\hline Cluster & $\begin{array}{c}\text { 1 (HZ-SC, HZ-PR, HZ-GO2, HZ-GO3, } \\
\text { HZ-DF1, HZ-DF2, and HZ-DF3) }\end{array}$ & (HA-DF1, HZ-GO1 and HA-DF2) & 3 (HA-BA and HA-SP) \\
\hline 1 (HZ-SC, HZ-PR, HZ-GO2, HZ-GO3, HZ- & 4.04 & 16.67 & 8.51 \\
DF1, HZ-DF2, and HZ-DF3) & - & 0.98 & 4.55 \\
\hline 2 (HA-DF1, HZ-GO1 and HA-DF2) & - & - & 0.58 \\
\hline 3 (HA-BA and HA-SP) & - & & \\
\hline
\end{tabular}

Genetics and Molecular Research 16 (3): gmr16038757 
The accumulated variance of the first two eigenvalues, generated by PCA was almost 70\%. As postulated by Sparks et al. (1999), in this situation, it is reasonable to study the divergence of the Helicoverpa populations in a bidimensional space, with negligible distortion degree (Figure 3). The same trend observed in UPGMA dendogram (Figure 1) and using the Tocher method (Table 4) was observed in PCA biplot, which also revealed three distinct clusters.

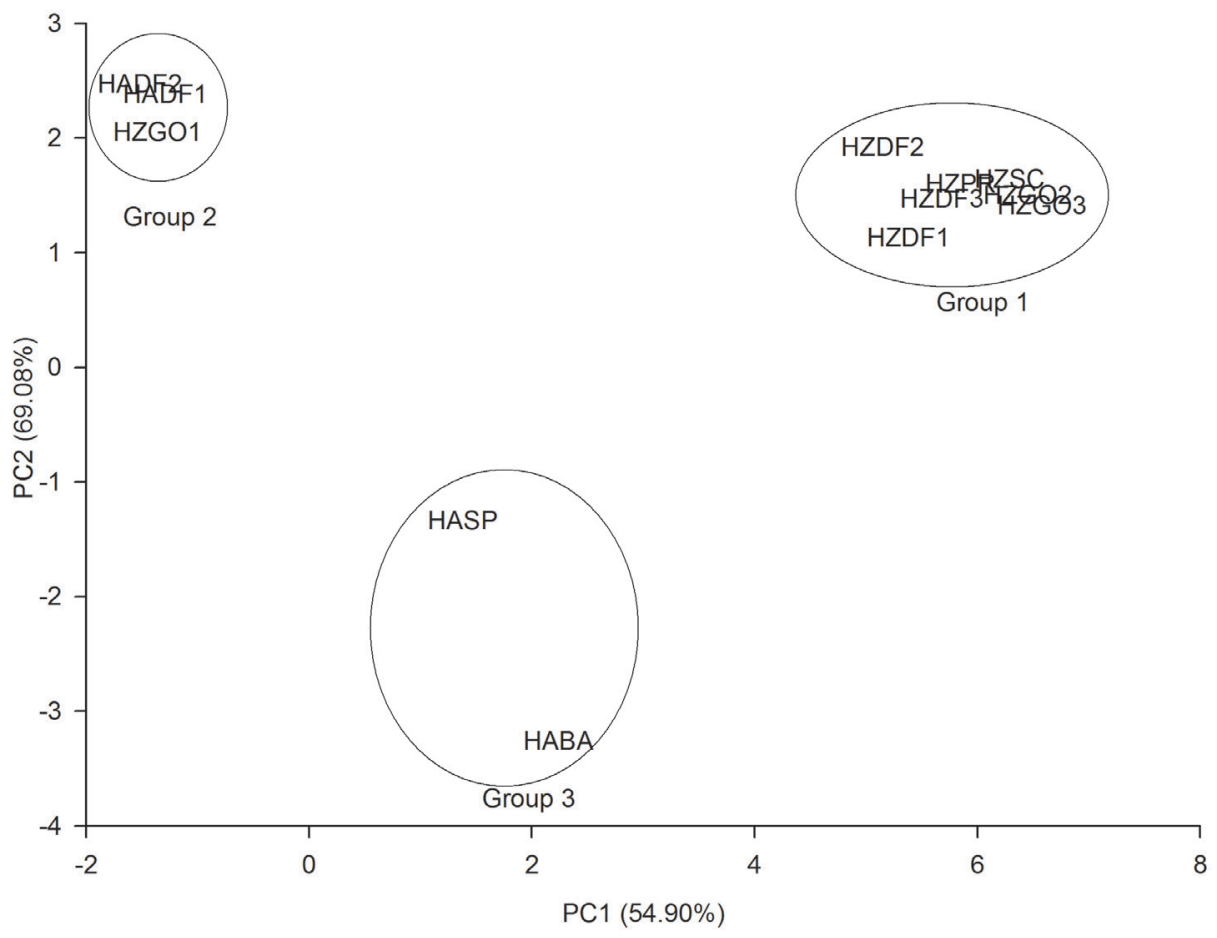

Figure 3. Scatter plot of principal component analysis of 117 polymorphic RAPD-PCR loci. Numbers in the parenthesis, located in the $\mathrm{X}$ - and $\mathrm{Y}$-axes, indicate cumulative percentages of the eigenvalues.

\section{DISCUSSION}

H. armigera has been recorded as feeding on 181 different plant species and this pest can attack the most important agricultural crops, such as: cotton, sorghum, soybeans, maize, vegetables, and subsistence crops like chickpea and pigeon pea (Subramanian and Mohankumar, 2006). As stated by King and Coleman (1989), its major natural enemies are Microplitis croceipes and Bracon brevicornis (Hymenoptera: Braconidae), Trichogramma spp, Eucelatoria bryani and Archytas marmoratus (Diptera: Tachnidae), Chrysopa spp (Neuroptera: Chrysopidae), Coleomegilla maculata (Coleoptera: Coccinellidae), and Geocoris spp (Hemiptera: Geocoridae). Besides, $H$ armigera larvae usually feed on flower buds and/ or fruits and because of this, they become protected from predators and parasites as well as exposed to sub lethal doses of insecticides. These authors also remark that the insecticides are often used to suppress Helicoverpa populations because of their availability, portability, and potential for quick intervention and prevention of serious plant damage.

Genetics and Molecular Research 16 (3): gmr16038757 
The greatest dissimilarity observed between the populations of $H$. armigera (HADF2 and HA-BA) cannot be explained only by the fact that they were collected in far apart geographic locations, because it is well known that this species can be dispersed at long distances (Farrow, 1984; Pedgley, 1985). According to Nibouche et al. (1998), this species can migrate as far as $2000 \mathrm{~km}$, and this value is greater than the distance between these two geographic sites. Feng et al. (2005) studied the long-distance migration of this species in China and based on radar observations concluded that the moth flight could reach up to $2000 \mathrm{~m}$ in altitude and, using airflows, moths can overcome distances over than $2000 \mathrm{~km}$, considering a three-day travel and a single night flight up to $700 \mathrm{~km}$.

Moreover, as supported by Jallow et al. (2004), Subramanian and Mohankumar (2006) and Behere et al. (2013), the differences between these two populations could be due to their natural hosts, since HA-BA caterpillars were collected infesting cotton plants, whereas HA-DF3 caterpillars were collected in soybean. There are many differences on agricultural practices between these crops, considering the flowering periods, pesticides spray and exposure to allelochemicals. Acording to Behere et al. (2013), the different cropping systems, to which $H$. armigera is exposed, may also be important underlying factors that contributed to population substructure differences. Host crops with short flowering periods (e.g., soybeans) generally support no more than one or two $H$. armigera generation; while hosts such as cotton with prolonged flowering periods are capable of supporting three consecutive generations. Populations that feed on cotton are under tremendous selection pressure from insecticide applications, and from varying levels of the allelochemical gossypol associated with different life stages and specific cotton varieties

In general, all studied $H$. zea populations were grouped into a single cluster, except HZ-GO1, indicating low genetic variability of this species in our samples. According to Pogue (2004), H. armigera is widely distributed in the Old World and, from this region, it was spread to Oceania. First proposed by Mallet et al. (1993) and confirmed by Behere et al (2007) through allozyme and mtDNA COI sequences respectively, using phylogeographic analyses of $H$. armigera and $H$. zea individuals, these authors postulated that $H$. zea evolved from a small portion of the larger $H$. armigera population (i.e., the "founder effect") that reached the American continent approximately 1.5 million years ago.

The populations of $H$. armigera assessed in the present study were subdivided into two distinct clusters, and one of these was composed by two geographically distant populations (HA-BA and HA-SP) and the other displayed an opposite trend. As previously discussed, $H$. armigera adults have long distance dispersion and adaptation to multiple host plants, which allow a high level of gene flow and a decrease on genetic variation. Furthermore, as postulated by Tay et al. (2013) and Leite et al. (2014), the invasion of H. armigera into the New World evolved from at least two maternal lineages. This fact gives support to the assignment of our H. armigera populations in two distinct clusters.

An important result found in the present study was the presence of a $H$. zea population (HZ-GO1) in a cluster with predominance of $H$. armigera populations. This observation can indicate potential interspecific crosses between these species. As observed by Laster and Hardee (1995) and Laster and Sheng (1995), despite their period for speciation, these two species can mate and generate fertile offspring under laboratory conditions.

In summary, the results of this research are significant because they indicate a possible interspecific cross between H. armigera and H. zea. Based on Leite et al. (2014), this recombination or introgression phenomena could allow the transfer of insecticide resistance

Genetics and Molecular Research 16 (3): gmr16038757 
genes from $H$. armigera to $H$. zea. On the other side, H. zea could donate genes for adaptation to environmental conditions of the American continent to $H$. armigera. Therefore, hybridization may enable the selection of breeds with enhanced hybrid vigor and the ability to rapidly adapt to current management and suppression methods used in Brazil.

\section{ACKNOWLEDGMENTS}

Cristina S. Bastos was supported by a fellowship from Conselho Nacional de Desenvolvimento Científico e Tecnológico (CNPq) and Heyder M. Lopes was supported by a scholarship from Coordenação de Aperfeiçoamento de Pessoal de Nível Superior (CAPES).

\section{REFERENCES}

Anbalagan S, Bharathiraja C, Pandiarajan J, Dinakaran S, et al. (2012). Use of random amplified polymorphic DNA (RAPD) to study genetic diversity within a population of blackfly, Simulium gravelyi from Palni hills, peninsular India. Biologia 67: 1195-1203. https://doi.org/10.2478/s11756-012-0104-z

Behere GT, Tay WT, Russell DA, Heckel DG, et al. (2007). Mitochondrial DNA analysis of field populations of Helicoverpa armigera (Lepidoptera: Noctuidae) and of its relationship to H. zea. BMC Evol. Biol. 7: 117. https://doi. org/10.1186/1471-2148-7-117

Behere GT, Tay WT, Russell DA and Batterham P (2008). Molecular markers to discriminate among four pest species of Helicoverpa (Lepidoptera: Noctuidae). Bull. Entomol. Res. 98: 599-603. https://doi.org/10.1017/S0007485308005956

Behere GT, Tay WT, Russell DA, Kranthi KR, et al. (2013). Population genetic structure of the cotton bollworm Helicoverpa armigera (Hübner) (Lepidoptera: Noctuidae) in India as inferred from EPIC-PCR DNA markers. PLoS One 8: e53448. https://doi.org/10.1371/journal.pone.0053448

Bhau BS, Mech J, Borthakur S, Bhuyan M, et al. (2014). Morphological and genetic diversity studies among populations of tea mosquito bug, Helopeltis theivora from Assam, India. Mol. Biol. Rep. 41: 7845-7856. https://doi.org/10.1007/ s11033-014-3678-4

Bird LJ and Downes SJ (2014). Toxicity and Cross-Resistance of Insecticides to Cry2Ab-Resistant and Cry2AbSusceptible Helicoverpa armigera and Helicoverpa punctigera (Lepidoptera: Noctuidae). J. Econ. Entomol. 107: 1923-1930. https://doi.org/10.1603/EC14230

Cruz CD (2013). GENES - a software package for analysis in experimental statistics and quantitative genetics. Acta Scientiarum 35: 271-276.

Czepack C, Albernaz KC, Vivan LM, Guimarães HO, et al. (2013). Primeiro registro de ocorrência de Helicoverpa armigera (Hubner) (Lepidoptera: Noctuidae) no Brasil. Pesqui. Agropecu. Trop. 43: 110-113. https://doi.org/10.1590/ $\underline{\text { S1983-40632013000100015 }}$

Farrow RA (1984). Detection of transoceanic migration of insects to a remote island in the Coral Sea, Willis Island. Aust. J. Ecol. 9: 253-272. https://doi.org/10.1111/j.1442-9993.1984.tb01362.x

Feng HQ, Wu KM, Ni YX, Cheng DF, et al. (2005). Return migration of Helicoverpa armigera (Lepidoptera: Noctuidae) during autumn in northern China. Bull. Entomol. Res. 95: 361-370. https://doi.org/10.1079/BER2005367

Guerra JCV, Jr., Issa MRC, Carneiro FE, Strapazzon R, et al. (2010). RAPD identification of Varroa destructor genotypes in Brazil and other regions of the Americas. Genet. Mol. Res. 9: 303-308. https://doi.org/10.4238/vol9-1gmr696

Jallow MFA, Cunningham JP and Zalucki MP (2004). Intra-specific variation for host plant use in Helicoverpa armigera (Hübner) (Lepidoptera: Noctuidae): Implications for management. Crop Prot. 23: 955-964. https://doi.org/10.1016/j. cropro.2004.02.008

King EG and Coleman RJ (1989). Potential for biological control of Heliothis species. Annu. Rev. Entomol. 34: 53-75. https://doi.org/10.1146/annurev.en.34.010189.000413

Laster ML and Hardee DD (1995). Intermating compatibility between North American Helicoverpa zea and Heliothis armigera (Lepidoptera: Noctuidae) from Russia. J. Econ. Entomol. 88: 77-80. https://doi.org/10.1093/jee/88.1.77

Laster ML and Sheng CF (1995). Search for hybrid sterility for Helicoverpa zea in crosses between the north american $H$. zea and H. armigera (Lepidoptera: Noctuidae) from China. J. Econ. Entomol. 88: 1288-1291. https://doi.org/10.1093/ 迆/88.5.1288

Leite NA, Alves-Pereira A, Corrêa AS, Zucchi MI, et al. (2014). Demographics and genetic variability of the new world bollworm (Helicoverpa zea) and the old world bollworm (Helicoverpa armigera) in Brazil. PLoS One 9: e113286.

Genetics and Molecular Research 16 (3): gmr16038757 
https://doi.org/10.1371/journal.pone.0113286

Mallet J, Korman A, Heckel D and King P (1993). Biochemical genetics of Heliothis and Helicoverpa (Lepidoptera: Noctuidae) and evidence for a founder event in Helicoverpa zea. Ann. Entomol. Soc. Am. 86: 189-197. https://doi. org/10.1093/aesa/86.2.189

Mastrangelo T, Paulo DF, Bergamo LW, Morais EGF, et al. (2014). Detection and genetic diversity of a heliothine invader (Lepidoptera: Noctuidae) from north and northeast of Brazil. J. Econ. Entomol. 107: 970-980. https://doi. org/10.1603/EC13403

McMichael M and Prowell DP (1999). Differences in amplified fragment-length polymorphisms in fall armyworm (Lepidoptera: Noctuidae) host strains. Ann. Entomol. Soc. Am. 92: 175-181. https://doi.org/10.1093/aesa/92.2.175

Nair R, Kalia V, Aggarwal KK and Gujar GT (2013). Variation in the cadherin gene sequence of Cry1Ac susceptible and resistant Helicoverpa armigera (Lepidoptera: Noctuidae) and the identification of mutant alleles in resistant strains. Curr. Sci. 104: 215-223.

Nibouche S, Bues R, Toubon JF and Poitout S (1998). Allozyme polymorphism in the cotton bollworm Helicoverpa armigera (Lepidoptera: Noctuidae): comparison of African and European populations. Heredity 80: 438-445. https:// doi.org/10.1046/j.1365-2540.1998.00273.x

Pedgley DE (1985). Windborne migration of Heliothis armigera (Hubner) (Lepidoptera: Noctuidae) to the British Isles. Entomol. Gaz. 36: 15-20.

Pogue M (2004). A new synonym of Helicoverpa zea (Boddie) and differentiation of adult males of $H$. zea and $H$. armigera (Hubner) (Lepidoptera: Noctuidae: Heliothinae). Ann. Entomol. Soc. Am. 97: 1222-1226. https://doi. org/10.1603/0013-8746(2004)097[1222:ANSOHZ]2.0.CO;2

Pogue MG (2013). Revised status of Chloridea Duncan and (Westwood), 1841, for the Heliothis virescens species group (Lepidoptera: Noctuidae: Heliothinae) based on morphology and three genes. Syst. Entomol. 38: 523-542. https:// doi.org/10.1111/syen. 12010

Rao CR (1952). Advanced statistical methods in biometric research. John Wiley, New York.

Rohlf FJ (2000). NTSYS-pc Numerical taxonomy and multivariate analysis system Version 2.1. Setauket. Exeter Software, New York.

Sneath PHA and Sokal RR (1973). Numerical taxonomy. W.H. Freeman, San Francisco.

Sparks TH, Scott WA and Clarke RT (1999). Traditional multivariate techniques: potential for use in ecotoxicology. Environ. Toxicol. Chem. 18: 128-137. https://doi.org/10.1002/etc.5620180206

Spadotto CA, Mingoti R and Holler WA(2014). Distribuição da produção agrícola e vias de acesso de pragas quarentenárias no Brasil. Campinas: Embrapa Gestão Territorial.

Specht A, Sosa-Gómez DR, Paula-Moraes SVD and Yano SAC (2013). Morphological and molecular identification of Helicoverpa armigera (Lepidoptera: Noctuidae) and expansion of its occurrence record in Brazil. Pesqui. Agropecu. Bras. 48: 689-692. https://doi.org/10.1590/S0100-204X2013000600015

Subramanian S and Mohankumar S (2006). Genetic variability of the bollworm, Helicoverpa armigera, occurring on different host plants. J. Insect Sci. 6: 1-8. https://doi.org/10.1673/2006 06 26.1

Tay WT, Soria MF, Walsh T, Thomazoni D, et al. (2013). A brave new world for an old world pest: Helicoverpa armigera (Lepidoptera: Noctuidae) in Brazil. PLoS One 8: e80134. https://doi.org/10.1371/journal.pone.0080134

Williams JGK, Kubelik AR, Livak KJ, Rafalski JA, et al. (1990). DNA polymorphisms amplified by arbitrary primers are useful as genetic markers. Nucleic Acids Res. 18: 6531-6535. https://doi.org/10.1093/nar/18.22.6531

Zalucki MP, Cunningham JP, Downes S, Ward P, et al. (2012). No evidence for change in oviposition behaviour of Helicoverpa armigera (Hübner) (Lepidoptera: Noctuidae) after widespread adoption of transgenic insecticidal cotton. Bull. Entomol. Res. 102: 468-476. https://doi.org/10.1017/S0007485311000848

Zhou X, Factor O, Applebaum SW and Coll M (2000). Population structure of pestiferous moth Helicoverpa armigera using RAPD analysis. Heredity 85: 251-256. https://doi.org/10.1046/j.1365-2540.2000.00738.x

Genetics and Molecular Research 16 (3): gmr16038757 